\title{
Genetic Variability, Correlation and Path Analysis in Ridge Gourd (Luffa acutangula (Roxb) L.)
}

\author{
M. Ananthan ${ }^{1}$ and V. Krishnamoorthy ${ }^{2} *$ \\ ${ }^{1}$ Horticultural Research Station, Thadiyankudisai, Dindigal District, \\ Tamil Nadu, India \\ ${ }^{2}$ Department of Horticulture, AC\&RI, TNAU, Madurai, Tamil Nadu, India \\ *Corresponding author
}

\begin{tabular}{|c|c|}
\hline & $\mathbf{R} A \mathbf{C} \mathbf{T}$ \\
\hline & \multirow{10}{*}{$\begin{array}{l}\text { The study was conducted at Department of Horticulture, Agricultural College and } \\
\text { Research Institute, Tamil Nadu Agricultural University, Madurai, Tamil Nadu during } \\
\text { September } 2013 \text { to August } 2016 \text { to study the performance of genetic variability, } \\
\text { heritability, genetic advance, correlation and path analysis for yield and yield attributing } \\
\text { characters namely first female flower node, days taken for first female flowering, number } \\
\text { of fruits per plant, fruit length, fruit weight }(\mathrm{g}) \text {, fruit yield per plant (kg) of twenty ridge } \\
\text { gourd genotypes collected from different parts of Tamil Nadu. The genotypes exhibited } \\
\text { higher percentage of genotypic coefficient variability, phenotypic coefficient variability } \\
\text { and genetic advance with fruit yield per plant }(31.55,32.86 \text { and } 62.39) \text { respectively and the } \\
\text { heritability was high with fruit length }(98 \%) \text {. The genotypic and phenotypic correlation } \\
\text { coefficients showed that the fruit yield per plant significantly contributed by fruit weight } \\
\text { (0.722 and } 0.681) \text {, fruit diameter }(0.426 \text { and } 0.393) \text {, number of fruits per plant }(0.504 \text { and } \\
0.477) \text { and first female flower node }(0.467 \text { and } 0.428) \text {. The path coefficient analysis } \\
\text { showed that number of fruits per plant exhibited significant positive direct effect on yield } \\
\text { per plant (1.4792) followed by fruit weight directly }(0.9346) \text { and indirectly }(0.7220)\end{array}$} \\
\hline & \\
\hline & \\
\hline $\mathrm{PCV}$, & \\
\hline $\begin{array}{l}\text { Path analysis, } \\
\text { Heritability. }\end{array}$ & \\
\hline Article Info & \\
\hline Accepted: & \\
\hline & \\
\hline & \\
\hline & \\
\hline
\end{tabular}

\section{Introduction}

Cucurbits form an important and big group of vegetable crops Ridge gourd (Luffa acutangula L) is one of the important members of this group. Ridge gourd has been cultivated for centuries in tropical, sub tropical and milder portions of temperate zones. Ridge gourd is popularly known as kalitori and also called as angled gourd, angled loofah, chinese okra, silky gourd and ribbed gourd. It is grown as mixed crop in the river bed areas and as mono crop is the garden land. The green immature fruits are cooked as vegetable and used in preparation of chutney and curries. Fruit is demulcent, diuretic and nutritive. The leaves are used is poultice in hemorrhoids, leprosy and splantis. The juice of fresh leaves is useful in granular conjunctivitis in children. The seeds possess purgative and emetic properties (Rahman et al., 2008). Every $100 \mathrm{~g}$ of edible portion of ridge gourd contains $0.5 \mathrm{~g}$ of fiber, 0.5 percent of protein, 0.34 percent of carbohydrate, $37 \mathrm{mg}$ of carotene, $5.0 \mathrm{mg}$ of vitamin C, $18 \mathrm{mg}$ of calcium and $0.5 \mathrm{mg}$ of iron (Hazra and Som, 2005). Besides their use as vegetable, it is also used in industries for cleaning and 
scrubbing machines. It is also compressed and made into soles for chappals is Japan.

Ridge gourd being a monoecious and cross pollinated crop and it exhibits considerable heterozygosity in population and does not suffer much due to inbreeding depression resulting is natural variability in the population. Thus provides ample scope for exploitation of existing variability on commercial scale to increase the production and productivity (Narasannavar et al., 2014). Evaluation of genotypes to assess the existing variability is considered as preliminary step is any crop improvement programme. In order to pursue an effective breeding programme, the present investigation was carried out to gather information on genetic variability, heritability, genetic gain, correlation and path analysis for different characteristics of sponge gourd.

\section{Materials and Methods}

The study was conducted at Department of Horticulture, Agricultural College and Research Institute, Tamil Nadu Agricultural University, Madurai, Tamil Nadu, India during September 2013 to August 2016. Totally twenty genotypes collected from Tamil Nadu the details of germplasm are given table 1. It was evaluated for three years during November, 2013, October, 2014 and August 2015. The seeds were sown in pits taken at a row spacing of $2.5 \mathrm{mt}$ and intra row spacing of $2.0 \mathrm{~m}$ in randamized block design. The observations were recorded in five randomly selected plants from each replication for first female flower node, days taken for first female flowering, number of fruits per plant, fruit length, fruit weight, fruit yield per plant $(\mathrm{kg})$. The data recorded were subjected to genotypic coefficient of variation (GCV), phenotypic coefficient of variation (PCV), broad sense heritability, correlation (genotypic and phenotypic) and path coefficient were computed by the methods suggested by Panse and Sukhatme (1967).

\section{Results and Discussion}

The analysis of variance revealed highly significant differences among twenty genotypes of ridge gourd for all the characters studied (Table 2). Environment play an important role in expression of various characters as the phenotypic coefficient variation (PCV) was found to be higher than the corresponding genotypic coefficient variation (GCV). The highest genotypic coefficient of variation was observed for yield per plant (31.55), fruit weight (28.86) and fruit length (27.69). However, a low genotypic coefficient of variation was noticed for days to first female flowering (13.88) and first female flower node (14.32).

High estimates of genotypic coefficient variation (GCV) and phenotypic coefficient variation were recorded for fruit yield per plant (31.55 and 32.86 per cent), fruit weight (28.86 and 29.41 per cent) and fruit length (27.69 and 27.88 per cent). The high magnitude of GCV further revealed the greater extent of variability presence in these characters suggesting good scope for improvement through selection of this crop similar results were reported in bitter gourd by Singh et al., (2002) and Kutty and Dharmatti (2004), Pumpkin by Kumar et al., (2010) and ridge gourd by Samadia (2011).

The genotypic coefficient variation alone does not fulfill the estimate the heritable variation, hence heritability and genetic advance were estimated. All the traits expressed high heritability which ranged from 92 to 98 percent suggesting the important role of genetic constitution in the expression of the characters and such traits were considered to be dependent from breeding importance. 
Table.1 Phenotypic and genotypic coefficient of variability, heritability and genetic advance as per cent mean of ridge gourd genotypes

\begin{tabular}{|c|l|c|c|c|c|}
\hline & Parameters & GCV & PCV & $\begin{array}{c}\text { Heritability } \\
(\boldsymbol{\%})\end{array}$ & GA (\%) \\
\hline $\mathbf{1}$ & First Female flower node & 14.32 & 14.69 & 95 & 28.73 \\
\hline $\mathbf{2}$ & $\begin{array}{l}\text { Days taken for first female } \\
\text { flowering }\end{array}$ & 13.88 & 14.21 & 95 & 27.92 \\
\hline $\mathbf{3}$ & Number of fruits / plant & 14.96 & 15.33 & 95 & 30.06 \\
\hline $\mathbf{4}$ & Fruit length (cm) & 27.69 & 27.88 & 98 & 56.66 \\
\hline $\mathbf{5}$ & Fruit diameter (cm) & 18.28 & 18.78 & 95 & 36.68 \\
\hline $\mathbf{6}$ & Individual fruit weight (g) & 28.86 & 29.41 & 96 & 58.37 \\
\hline $\mathbf{7}$ & Fruit yield per plant (kg) & 31.55 & 32.86 & 92 & 62.39 \\
\hline
\end{tabular}

Table.2 Genotypic $(\mathrm{G})$ and phenotypic $(\mathrm{P})$ correlation coefficients in ridge gourd genotypes

\begin{tabular}{|c|c|c|c|c|c|c|c|c|}
\hline $\begin{array}{l}\text { Parameter } \\
\text { S }\end{array}$ & & $\begin{array}{c}\text { Ist } \\
\text { Femal } \\
\text { e } \\
\text { flower } \\
\text { node }\end{array}$ & $\begin{array}{c}\text { Days } \\
\text { taken for } \\
\text { first } \\
\text { female } \\
\text { flowerin } \\
\mathrm{g} \\
\end{array}$ & $\begin{array}{c}\text { Numbe } \\
\text { r of } \\
\text { fruits / } \\
\text { plant }\end{array}$ & $\begin{array}{l}\text { Fruit } \\
\text { length } \\
(\mathrm{cm})\end{array}$ & $\begin{array}{c}\text { Fruit } \\
\text { diamete } \\
\mathbf{r}(\mathbf{c m})\end{array}$ & $\begin{array}{l}\text { Individua } \\
\text { I fruit } \\
\text { weight (g) }\end{array}$ & $\begin{array}{c}\text { Fruit } \\
\text { yield per } \\
\text { plant (kg) }\end{array}$ \\
\hline & & 1 & 2 & 3 & 4 & 5 & 6 & 7 \\
\hline \multirow{2}{*}{$\begin{array}{l}\text { Ist Female } \\
\text { flower } \\
\text { node }\end{array}$} & $\mathbf{G}$ & 1.000 & $0.721 * *$ & $0.759 * *$ & 0.270 & $0.641 * *$ & $0.658 * *$ & $0.467 *$ \\
\hline & $\mathbf{P}$ & 1.000 & $0.699 * *$ & $0.720 * *$ & 0.266 & $0.614 * *$ & $0.627 * *$ & $0.428 *$ \\
\hline \multirow{2}{*}{$\begin{array}{l}\text { Days taken } \\
\text { for first } \\
\text { female } \\
\text { flowering }\end{array}$} & $\mathbf{G}$ & & 1.000 & $0.794 * *$ & 0.459 & $0.647 * *$ & 0.438 & 0.312 \\
\hline & $\mathbf{P}$ & & 1.000 & $0.754 * *$ & 0.439 & $0.618 * *$ & 0.409 & 0.288 \\
\hline \multirow{2}{*}{$\begin{array}{l}\text { Number of } \\
\text { fruits / } \\
\text { plant }\end{array}$} & $\mathbf{G}$ & & & 1.000 & $\begin{array}{c}0.605 * \\
*\end{array}$ & $0.822 * *$ & 0.497 & $0.504 *$ \\
\hline & $\mathbf{P}$ & & & 1.000 & $\begin{array}{c}0.588 * \\
*\end{array}$ & $0.773 * *$ & 0.475 & $0.477 *$ \\
\hline \multirow{2}{*}{$\begin{array}{l}\text { Fruit } \\
\text { length } \\
\text { (cm) }\end{array}$} & $\mathbf{G}$ & & & & 1.000 & 0.230 & 0.366 & 0.200 \\
\hline & $\mathbf{P}$ & & & & 1.000 & 0.220 & 0.361 & 0.189 \\
\hline \multirow{2}{*}{$\begin{array}{l}\text { Fruit } \\
\text { diameter } \\
(\mathrm{cm})\end{array}$} & $\mathbf{G}$ & & & & & 1.000 & 0.412 & $0.426^{*}$ \\
\hline & $\mathbf{P}$ & & & & & 1.000 & 0.387 & $0.393 *$ \\
\hline \multirow{2}{*}{$\begin{array}{l}\text { Individual } \\
\text { fruit } \\
\text { weight (g) }\end{array}$} & G & & & & & & 1.000 & $0.722 * *$ \\
\hline & $\mathbf{P}$ & & & & & & 1.000 & $0.681 * *$ \\
\hline \multirow{2}{*}{$\begin{array}{c}\text { Fruit yield } \\
\text { per plant } \\
(\mathrm{kg})\end{array}$} & $\mathbf{G}$ & & & & & & & 1.000 \\
\hline & $\mathbf{P}$ & & & & & & & 1.000 \\
\hline
\end{tabular}


Table.3 Path coefficient analysis for direct and indirect effects of ridge gourd genotypes for yield and its related attributes

\begin{tabular}{|l|c|c|c|c|c|c|c|}
\hline $\begin{array}{l}\text { Name of } \\
\text { genotypes }\end{array}$ & $\begin{array}{c}\text { First } \\
\text { Female } \\
\text { flower } \\
\text { node }\end{array}$ & $\begin{array}{c}\text { Days } \\
\text { taken for } \\
\text { first } \\
\text { female } \\
\text { flowering }\end{array}$ & $\begin{array}{c}\text { Numbe } \\
\text { r of } \\
\text { fruits / } \\
\text { plant }\end{array}$ & $\begin{array}{c}\text { Fruit } \\
\text { length } \\
\text { (cm) }\end{array}$ & $\begin{array}{c}\text { Fruit } \\
\text { diamete } \\
\text { r (cm) }\end{array}$ & $\begin{array}{c}\text { Individua } \\
\text { I fruit } \\
\text { weight (g) }\end{array}$ & $\begin{array}{c}\text { Fruit yield } \\
\text { per plant } \\
\text { (kg) }\end{array}$ \\
\hline $\begin{array}{l}\text { Ist Female } \\
\text { flower node }\end{array}$ & $\mathbf{- 0 . 6 3 9 6}$ & -0.1363 & 1.1221 & -0.1796 & -0.3141 & 0.6146 & 0.4670 \\
\hline $\begin{array}{l}\text { Days taken } \\
\text { for first } \\
\text { female } \\
\text { flowering }\end{array}$ & -0.4612 & $\mathbf{- 0 . 1 8 9 0}$ & 1.1747 & -0.3051 & -0.3168 & 0.4094 & 0.3120 \\
\hline $\begin{array}{l}\text { Number of } \\
\text { fruits / plant }\end{array}$ & -0.4851 & -0.1501 & $\mathbf{1 . 4 7 9 2}$ & -0.4022 & -0.4027 & 0.4649 & 0.5040 \\
\hline $\begin{array}{l}\text { Fruit length } \\
\text { (cm) }\end{array}$ & -0.1727 & -0.0867 & 0.8947 & $\mathbf{- 0 . 6 6 4 9}$ & -0.1129 & 0.3422 & 0.2000 \\
\hline $\begin{array}{l}\text { Fruit } \\
\text { diameter } \\
\text { (cm) }\end{array}$ & -0.4102 & -0.1223 & 1.2161 & -0.1532 & $\mathbf{- 0 . 4 8 9 8}$ & 0.3851 & 0.4260 \\
\hline $\begin{array}{l}\text { Individual } \\
\text { fruit weight } \\
\text { (g) }\end{array}$ & -0.4206 & -0.0828 & 0.7358 & -0.2435 & -0.2018 & $\mathbf{0 . 9 3 4 6}$ & 0.7220 \\
\hline
\end{tabular}

Residual effect: 0.5284

Among the seven characters studied fruit length and fruit weight (98 and 92 per cent) showed high heritability coupled with high genetic advance (58.37 and 56.66 per cent) which showed that these two traits had additive gene effect and they are more reliable for effective selection. Similar results were reported by Samadia (2011) in ridge gourd and Dey et al., (2009) in bitter gourd.

\section{Association analysis}

The correlation coefficients between yield and its components and inter correlation among the different yield attributes estimated were given in table 3 . In general genotypic correlation coefficients were higher magnitude than phenotypic correlation coefficients. The fruit yield per vine was found to be significantly and positively correlated with fruit weight (0.722 and 0.681), fruit diameter (0.426 and 0.393), number of fruits per plant (0.504 and 0.477) and first female flowering node ( 0.467 and 0.428$)$ at genotypic and phenotypic level indicating that any increase in these four characters would bring about an enhancement in the yield. Further individual fruit was significantly and positively correlated with first female flowering node. Suggesting that improving this fruit will ensure the increase in fruit weight. Similar results were reported by Lakshmi et al., (2002) in pumpkin and Cheema et al., (2011) in musk melon.

Path analysis showed that among seven traits number of fruits per plant contributed the maximum positive direct effect (1.479) 
followed by fruit weight (0.935) the fruit length had highest negative direct effect (0.665 ) followed by first female flower node ($0.640)$. The fruit weigh is also indirectly and positively influenced by first female flowering node (0.615). The negative effect of first female flower node is desirable because this fruit is beneficial and contribute indirectly positively to the yield per vine. Similar results were reported by Prabha et al., (2008) in ridge gourd, Shivananda et al., (2003) in pumpkin.

\section{References}

Cheema, K.L., Iqbal, M., Niaz, S., and Shafique, M., 2011. Assessment of variability of muskmelon. Int. J. Veg. Sci., 17: 322-332.

Hazra, P. and Som, M.G., 2005. Vegetable Science. Kalyani publishers, New Delhi. pp. 5-10.

Kumar, J., Munshi, A.D., Kema, R., and Sureja, A.K., 2010. Studies on Heterosis in slicing cucumber. Indian J. Hort., 67(2): 197-201.

Lakshmi, K., Haribabu and Reddy, G.L.K., 2002. Character association and path coefficient studies in pumpkin (Cucurbita moschata Dutch. Ex. Poir.). The Andhra Agrl. J., 49(1\&2): 80-85.
Narasannavar, A., Gasti, V.D., Malghan.S and Kumara, B.R., 2014. Gene action and combining ability analysis for yield and yield-related traits in ridge gourd[Luffa acutangula (L.) Roxb.].Global J.Hort., (14). 2249-4626.

Panse, V. C. and Sukhatme, P. V., 1967. Statistical methods for agricultural workers, Indian Council of Agricultural Research, New Delhi.

Prabha, R.J., Latha, T.P., Sankar, C.R., and Rao, V.S., 2008. Character association and path coefficient studies in ridge gourd [Luffa acutangula (Roxb.) L.]. The Andhra Agrl. J., 55(1): 63-67.

Rahman, A. H., Anisuzzaman, M.M., Ahmed, M.F. Rafiul, A.K.M., and Naderuzzaman, A.T.M., 2008. Study of nutritive value and medicinal value of cultivated cucurbits. J. Appl. Sci. Res., 4 (5): 555-558.

Samadia, D.K., 2002. Performance of bottle gourd genotypes under hot arid environment. Indian J. Hort., 59: 167170.

Shivananada, M. M., Madalageri, M.B., Chikkur, S.S., Mohankumar, A.B., and Yathiraj, K., 2013. Correlation and path co-efficient studies in pumpkin (Cucurbita moschata Dutch. Ex. Poir.). Int. J. Agric Sci., 9(1): 76-79.

\section{How to cite this article:}

M. Ananthan and V. Krishnamoorthy. 2017. Genetic Variability, Correlation and Path Analysis in Ridge Gourd (Luffa acutangula (Roxb) L.). Int.J.Curr.Microbiol.App.Sci. 6(6): 3022-3026. doi: https://doi.org/10.20546/ijcmas.2017.606.359 